запасом, залежить від загального активного запасу мовних засобів (слів, значень, моделей словосполучень і речень, типових інтонацій, зв'язків і відношень у тексті), сукупності навичок для цілеспрямованого застосування засобів мови.

Водночас разом із уведенням активних форм має змінитися і ставлення до навчання, що залишається в цілому традиційним. Дійсно, є слушним зауваження науковців: на зміну існуючому уявленню про те, що тренінгові форми допомагають у легкій, розважальній формі опановувати навчальний матеріал, має прийти розуміння, що ділові ігри, тренінги вимагають напруженої інтелектуальної праці кожної хвилини навчального часу. Використання на заняттях рольових ділових ігор сприяє якісній зміні ставлення до майбутньої професійної діяльності, як показує проведена дослідна робота: зростає прагнення встановлювати продуктивні відносини 3 колегами, можливості професійного розвитку, прагнення внести елемент творчості у професійну діяльність. 3'являється потреба більш глибокого і точного сприйняття усного слова, вміння виокремлювати 3 почутого раціональне зерно, коректно і стисло ставити питання, точно і стисло відповідати на питання партнерів, «шліфується» вміння слухати і чути. Застосування відеозйомки дає змогу побачити допущені помилки в мовленні, оцінити манеру здійснення дискусії, зовнішній вигляд, жестикуляцію - все, що може «зробити» комунікацію переконливішою або навпаки не донести до аудиторії важливої інформації.

Отже, формування комунікативної компетентності майбутніх економістів - це складний динамічний процес, що потребує цілісної системи роботи з урахуванням усіх структурних компонентів досліджуваного процесу в поєднанні аспектів розуміння різноманітних навчальних і життєвих ситуацій, умінь практичного використання набутих знань та, відповідно, усвідомлення необхідності самовдосконалення наявного особистісного рівня сформованості комунікативної компетентності. У наступних публікаціях зупинимося на більш детальному аналізі організаційно-педагогічних умов формування комунікативної компетентності майбутніх економістів.

\title{
Література
}

1. Бакум 3. П. Формування комунікативної компетентності майбутніх економістів: теоретикопрактичний аспект проблеми / З. П. Бакум, С. М. Хоцкіна // Педагогічні науки: зб. наук. пр. Вип. LVIII - Ч. 2. - Херсон : ХДУ, 2011. - С. 278-282. 2. Педагогический энциклопедический словарь/ гл. ред. Б. М. Бим-Бад. - М. : Большая Российская энциклопедия, 2003. - 527 с.: ил. 3. Рибалка В. В. Аксіологічні основи психологічної культури особистості: [навч.-метод. посіб.] / В. В. Рибалка. - Чернівці : Технодрук, 2009. - 228 с. 4. Хомич Л. О. Аксіологічні основи професійної підготовки майбутнього вчителя / Л. О. Хомич // Аксіологічний підхід - основа формування цілісності особистості майбутнього педагога: [монографія]; [за заг. ред. Л. О. Хомич]. - Київ-Ніжин : Видавець ПП Лисенко М. М., 2010. - С. 6-22.

УДК 177.9:340.11

Світлана Соколова

\section{КРИТЕРІЇ, ПОКАЗНИКИ ТА РІВНІ СФОРМОВАНОСТІ ПРАВОВОЇ КУЛЬТУРИ МАЙБУТНІХ ІНЖЕНЕРІВ-ПЕДАГОГІВ}

Соколова С. В. Критерії, показники та рівні сформованості правової культури майбутніх інженерів-педагогів.

У статті розглядаються мотиваційно-ціннісний, когнітивно-інформаційний, діяльнісноповедінковий, морально-особистісний та оцінно-рефлексивний критерії, показники і рівні сформованості правової культури майбутніх інженерів-педагогів. Визначено, що саме критерій $€$ основою для оцінки рівнів сформованості правової культури.

Ключові слова: критерії, показники, рівні сформованості правової культури майбутніх інженерів-педагогів, правова культура.

Соколова С. В. Критерии, показатели и уровни сформированности правовой культуры будущих инженеров-педагогов.

В статье рассматриваются мотивационно-ценностный, когнитивно-информационный, деятельностно-поведенческий, нравственно-личностный и оценочно-рефлексивный критерии, показатели и уровни сформированности правовой культуры будущих инженеров-педагогов. 
Определенно, что именно критерий является основанием для оценки уровней сформированности правовой культуры.

Ключевые слова: критерии, показатели, уровни сформированности правовой культуры будущих инженеров-педагогов, правовая культура.

Sokolova S. V. Criteria, indicators and legal culture levels formation of future engineer-teachers.

The article considers motivational evaluative, cognitive informational, active-behavioral, moral, personal and appreciable-reflexive criteria, indicators and levels of formation of future engineers and educators' legal culture. It is defined that the criterion is the basic unit for assessing the levels of legal culture formation.

Key words: criteria, indicators, legal culture levels formation of future engineer-teachers, legal culture.

В українській педагогіці накопичено чималий досвід формування правової культури молодого покоління, оскільки у процесі підготовки спеціаліста важливо не лише озброїти його фаховими знаннями, уміннями та навичками професійної діяльності, а й сформувати в нього відповідний світогляд, моральні, правові та інші якості особистості.

Суттєве значення має рівень культури й освіченості майбутніх фахівців професійної школи, які здійснюватимуть у майбутньому навчально-виховну діяльність у професійнотехнічній сфері. Тому в технічному університеті випускник має отримати таку професійну підготовку, яка б забезпечила належний рівень професіоналізму, відповідну ефективність здійснення правовиховної роботи серед учнівської молоді.

Аналіз наукової літератури свідчить про наявність значної кількості праць, присвячених дослідженню правової культури, іiі критеріїв, показників і рівнів сформованості в різних аспектах (А. Аверін, А. Морозов, В. Ряйко, М. Козяр, С. Совва, С. Нефедов та ін.).

Метою статті є характеристика критеріїв, показників і рівнів сформованості правової культури майбутніх інженерів-педагогів.

Спочатку слід унести визначеність до змісту терміна «критерій». Різні словники подають майже однакове визначення поняття «критерій». Критерій (від грец. kriterion - засіб для судження) - це:

а) ознака, на підставі якої проводиться оцінка, визначення або класифікація чого-небудь; мірило судження; оцінки якого-небудь явища;

б) ознака, що є основою для оцінки, може бути розбита на показники діяльності, теоретично розроблені показники рівня сформованості якості особистості, 3 якими порівнюються досягнуті результати $[1$, с. 6$]$.

На думку А. Твердохліба, під критерієм розуміють ідеальний зразок, еталон, що виражає вищий, найдосконаліший рівень сформованості будь-яких якостей особистості, порівняно 3 яким можна встановити ступінь відповідності й наближення реального до ідеального, до рівня норми, еталону, ідеалу [2, с. 78 ].

О. Савченко, Т. Байбара визначають критерії як реальні, точно обрані ознаки, величини, що $€$ вимірниками об'єктів оцінювання. Ю. Туранов, В. Урський уважають, що критерії - це мірило оцінювання вказаних параметрів, котрі описуються певними показниками.

Питання визначення критеріїв, показників, рівнів сформованості правової культури різних фахівців розглядалося багатьма науковцями. Зокрема, С. Сливка основними критеріями правової культури юриста вважає:

1) знання правових та інших соціальних норм (моральних, естетичних, корпоративних тощо);

2) повагу правника до права (як позитивного, так і природного), моральних норм, почуття службового обов'язку;

3) уміння і навички правоохоронця реалізовувати правові, психологічні та інші норми і знання;

4) готовність виконувати свій службовий обов'язок, діяти правомірно в будь-якій ситуації;

5) власна правомірна поведінка юриста під час здійснення його професійної діяльності [3, с. 69].

Щодо проблеми вимірів у педагогіці поки що немає однозначного розв'язання. Вимір передбачає наявність таких складників: об'єкт виміру, спостерігач, міра виміру (еталон, за яким визначаються показники), вимірник (інструмент, за допомогою якого проводяться виміри), метод виміру (сукупність прийомів або операцій, за допомогою яких визначаються значення показника), результат виміру, виражений в абсолютних або відносних одиницях. 
Згідно 3 цим об'єктом виміру в нашому випадку є майбутній інженер-педагог, його типологічні й індивідуальні якості (показники) та їх зміна під впливом чинників навчальновиховного процесу ВНЗ.

Аналіз сутнісних, структурних і функціональних характеристик професійної діяльності інженера-педагога, сутності правової культури інженера-педагога, а також урахування вимог до випускника ВНЗ та структури правової культури дозволили визначити систему критеріїв, показників і рівнів сформованості правової культури майбутніх інженерів-педагогів. Нами було визначено 5 критеріїв оцінки сформованості правової культури майбутніх інженерів-педагогів, кожний із яких, у свою чергу, було оцінено за 5 показниками. Перший критерій стосується мотивів і правосвідомості (мотиваційно-ціннісний критерій), другий - правової освіченості (когнітивно-інформаційний критерій), третій - освітньо-правової діяльності (діяльнісноповедінковий критерій), четвертий - дотримання морально-правових норм (моральноособистісний критерій), п'ятий - педагогічно-правової рефлексії (оцінно-рефлексивний критерій).

Зупинимося докладніше на кожному критерії сформованості правової культури майбутнього інженера-педагога та відповідних показників.

1. Мотиваційно-ціннісному критерію відповідають такі показники, як мотиви вивчення освітнього права; інтерес до освітнього законодавства; розуміння (усвідомлення) цінності освітнього права; стійкість правових поглядів і переконань; свідоме ставлення до правових норм освітнього законодавства і необхідності їх виконання.

2. Когнітивно-інформаційному критерію відповідають такі показники, як знання освітнього права (обсяг, глибина, системність); розуміння основних освітньо-правових понять і категорій; конкретні й специфічні знання освітнього законодавства; практичні знання щодо розв'язання правових завдань і ситуацій у сфері освіти; опанування правового досвіду.

3. Діяльнісно-поведінковому - дотримання правових норм і правослухняна поведінка; уміння аналізувати правові явища й ситуації та прогнозувати можливі правові наслідки дій; морально-правові орієнтації у суб'єкт-суб'єктних взаємовідносинах; уміння використовувати в роботі різні види джерел освітньо-правової інформації.

4. Морально-особистісному - глибоке переконанання в необхідності свідомого виконання вимог освітнього законодавства, сприйняття освітнього права і права взагалі як найвищої соціальної цінності; готовність до виконання професійного обов'язку; уміння переконливо відстояти свою точку зору у складних правових ситуаціях, аргументувати свою позицію; дотримання норм професійної етики у спілкуванні з іншими людьми.

5. Оцінно-рефлексивному - прагнення до правового самоконтролю, саморегуляції правової поведінки; уміння визначати об'єктивність власних правових міркувань, оцінок (самоконтроль правового мислення); правова рефлексія.

Отже, на основі розроблених критеріїв і показників було виокремлено п'ять рівнів сформованості правової культури майбутнього інженера-педагога: найвищий, високий, середній, базовий, елементарний.

Охарактеризуємо кожен рівень.

1. Елементарний рівень характеризується такими позиціями: майбутній інженер-педагог має примітивні уявлення про політичне і правове життя в Україні, про систему освіти України, має розрізнені знання з освітніх норм права, у нього відсутнє прагнення дотримання норм права, немає інтересу до права.

2. Базовий рівень характеризується такими позиціями: інженер-педагог має знання основних норм права, необхідних для професійної діяльності, усвідомлює роль правової культури в структурі майбутньої професійної діяльності і загальної культури особистості, використання норм освітнього права у професійно значущих ситуаціях не систематичне.

3. Середній рівень: у повному обсязі має знання про систему освіти України, правовий статус учасників освітнього процесу, особливості діяльності навчальних закладів, має сформовані правові інтереси і цілі, прагне використовувати правові норми в професійній діяльності, має потребу в опануванні досвіду правової діяльності.

4. Високий рівень: майбутній спеціаліст у повному обсязі згідно з державними освітніми стандартами володіє знаннями про історичний розвиток та вплив права на освіту в Україні, системні та структурні елементи освіти, форми ії здобуття, міжнародні правові стандарти у сфері освіти, правовий статус учасників освітнього процесу, особливості діяльності навчальних 
закладів, нормативно-правове регулювання навчально-виховного процесу та педагогічних відносин, засади правового регулювання коміторних правовідносин, суміжних із педагогічними правовідносинами, має сформовану правосвідомість, уміє всебічно оцінювати правову ситуацію та знаходити оптимальне рішення, уміє використовувати норми права в складних ситуаціях.

5. Найвищий рівень характеризується: наявністю системних правових знань, умінням саморегуляції, високою соціальною рефлексією, самовдосконаленням особистої правової культури, інженер-педагог має яскраво виражену правову свідомість, прагнення до правового самоконтролю, прагнення творчого використання правових норм у професійній діяльності, активно опановує правовий досвід.

Отже, аналіз психолого-педагогічної літератури, практики професійної підготовки інженерів-педагогів э можливість виявити такі критерії оцінки рівня сформованості їх правової культури: мотиваційно-ціннісний, когнітивно-інформаційний, діяльнісно-поведінковий та оцінно-рефлексивний.

1. Белкин А. С. Диссертационный совет по педагогике (опыт, проблемы, перспективы) // А. С. Белкин, Е. В. Ткачев. - Екатеринбург : УрГПУ, 2005 - 248 с. 2. Сливка С. С. Юридична деонтологія: [підручник] / С. С. Сливка. - [3-те вид., перероб. та доп.]. - К. : Юрінком Інтер, 2002. 736 с. 3. Твердохліб Л. В. Формування правової культури старшокласників у навчальних закладах нового типу : автореф. дис. на здобуття наук. ступеня канд. пед. наук : спец. 13.00.01 «Теорія та історія педагогіки» / Л. В. Твердохліб. - Луганськ, 1999. - 22 с.

УДК 510.8:005.35:005.932

Владислав Фадєєв

\section{ТЕОРЕТИЧНІ АСПЕКТИ МОДЕЛЮВАННЯ УПРАВЛІННЯ ОСВІТНІМИ РЕСУРСАМИ ВИЩОЇ ОСВІТИ В УКРАЇНI}

Фадєєв В. І. Теоретичні аспекти моделювання управління освітніми ресурсами вищої освіти в Україні.

Стаття присвячена аналізу теоретичних особливостей моделювання управління освітніми ресурсами вищих навчальних закладів. Досліджено особливості застосування системного підходу до моделювання управління освітніми ресурсами вищої освіти України.

Ключові слова: система, моделювання, управління, освітні ресурси, вищі навчальні заклади.

Фадеев В.И. Теоретические аспекты моделирования управления образовательными ресурсами высшего образования в Украине.

Статья посвящена анализу теоретических особенностей моделирования управления образовательными ресурсами высших учебных заведений. Исследованы особенности применения системного подхода к моделированию управления образовательными ресурсами высшего образования Украины.

Ключевые слова: система, моделирование, управление, образовательные ресурсы, высшие учебные заведения.

Fadeev V. I. The theoretical aspects of modeling the management of educational resources of higher education in Ukraine

This article analyzes the characteristics of theoretical modeling of management of educational resources of higher education. The features of a systems approach to modeling the management of educational resources of higher education in Ukraine are researched.

Key words: system, modeling, management, educational resources, higher education.

Розвиток і функціонування освіти як відкритої, динамічної соціально-педагогічної системи потребує створення ефективної системи управління, яка має досить складний і розгалужений характер. Це вимагає розгляду певних методологічних засад створення моделі системи управління системою вищої освіти, у тому числі освітніми ресурсами вищих навчальних закладів України. Під час процесу організації цього процесу особливої уваги набуває розгляд 